\title{
Serological, Molecular and Culture-Based Diagnosis of Lentiviral Infections in Small Ruminants
}

\author{
Aphrodite I. Kalogianni ${ }^{1, * \mathbb{D}}$, Ioannis Stavropoulos ${ }^{2}$, Serafeim C. Chaintoutis ${ }^{3} \mathbb{D}$, Ioannis Bossis ${ }^{2} \mathbb{D}$ \\ and Athanasios I. Gelasakis $1, *$ (D)
}

1 Laboratory of Anatomy and Physiology of Farm Animals, Department of Animal Science, School of Animal Biosciences, Agricultural University of Athens (AUA), Iera Odos 75 Str., 11855 Athens, Greece

2 Laboratory of Animal Husbandry, Department of Agricultural Sciences, School of Agriculture, Forestry and Natural Resources, Aristotle University of Thessaloniki (AUTh), 54124 Thessaloniki, Greece; istavrop@agro.auth.gr (I.S.); bossisi@agro.auth.gr (I.B.)

3 Diagnostic Laboratory, School of Veterinary Medicine, Faculty of Health Sciences, Aristotle University of Thessaloniki (AUTh), 11 Stavrou Voutyra Str., 54627 Thessaloniki, Greece; schainto@vet.auth.gr

* Correspondence: afrokalo@aua.gr (A.I.K.); gelasakis@aua.gr (A.I.G.)

check for updates

Citation: Kalogianni, A.I.; Stavropoulos, I.; Chaintoutis, S.C.; Bossis, I.; Gelasakis, A.I. Serological, Molecular and Culture-Based Diagnosis of Lentiviral Infections in Small Ruminants. Viruses 2021, 13, 1711. https://doi.org/10.3390/ v13091711

Academic Editors: Craig Miller and Silvia Preziuso

Received: 30 June 2021

Accepted: 25 August 2021

Published: 27 August 2021

Publisher's Note: MDPI stays neutral with regard to jurisdictional claims in published maps and institutional affiliations.

Copyright: (c) 2021 by the authors. Licensee MDPI, Basel, Switzerland. This article is an open access article distributed under the terms and conditions of the Creative Commons Attribution (CC BY) license (https:// creativecommons.org/licenses/by/ $4.0 /)$.

\begin{abstract}
Small ruminant lentiviruses (SRLVs) infections lead to chronic diseases and remarkable economic losses undermining health and welfare of animals and the sustainability of farms. Early and definite diagnosis of SRLVs infections is the cornerstone for any control and eradication efforts; however, a "gold standard" test and/or diagnostic protocols with extensive applicability have yet to be developed. The main challenges preventing the development of a universally accepted diagnostic tool with sufficient sensitivity, specificity, and accuracy to be integrated in SRLVs control programs are the genetic variability of SRLVs associated with mutations, recombination, and cross-species transmission and the peculiarities of small ruminants' humoral immune response regarding late seroconversion, as well as intermittent and epitope-specific antibody production. The objectives of this review paper were to summarize the available serological and molecular assays for the diagnosis of SRLVs, to highlight their diagnostic performance emphasizing on advantages and drawbacks of their application, and to discuss current and future perspectives, challenges, limitations and impacts regarding the development of reliable and efficient tools for the diagnosis of SRLVs infections.
\end{abstract}

Keywords: small ruminant lentiviruses; maedi-visna; caprine arthritis-encephalitis; diagnosis; serological methods; molecular methods; ELISA; PCR; cell cultures

\section{Introduction}

Small ruminant lentiviruses (SRLVs) are a group of non-oncogenic viruses of the family Retroviridae, that infect both sheep and goats causing chronic, incurable, inflammatory diseases known as maedi-visna (MV) and caprine arthritis-encephalitis (CAE) [1]. SRLVs are characterized by high genetic variability among genotypes (genotypes A (subtypes A1-A22), B (subtypes B1-B5), C, and E (subtypes E1-E2)) [2-4]. Nevertheless, they display similar pathogenesis affecting lungs, mammary gland, central nervous system and joints, and similar tropism by infecting monocytes/macrophages and dendritic cells [2,3,5]. Clinical manifestations of the disease in chronically infected animals include pneumonia and mastitis, encephalitis and arthritis; however, most infected animals are usually asymptomatic due to the slow and progressive evolution of the infection [1,5-7]. The primary source of infection for newborn lambs is the consumption of colostrum and milk from infected ewes (lactogenic route) [8,9]. Horizontal transmission via respiratory secretions is also significant, especially in intensively reared small ruminants $[10,11]$, whereas transplacental transmission [12] and transmission via semen during mating or artificial insemination are also possible, but their significance and extent has not been thoroughly studied $[8,13]$. 
The economic impact of the SRLVs global spreading on the small ruminant sector has not yet been fully elucidated; however, it is widely recognized as a major cause of (i) increased replacement rate, resulting from the involuntary culling of animals with clinical disease, (ii) decreased lambs' growth rate and milk production (quantitatively and qualitatively) due to the adverse effects on the secretory capacity of the mammary gland and (iii) restrictions in breeding stocks and semen trading [2,14-16].

Considering the lack of efficient treatment or vaccination, early and accurate diagnosis of SRLVs infections is paramount for the successful implementation of control programs, the eradication of MV and CAE, and the accreditation of SRLV-free regions and farms. Diagnosis of SRLVs is based either on the detection of SRLV-specific antibodies with serological tests such as agar gel immunodiffusion (AGID), enzyme-linked immunosorbent assay (ELISA), radioimmunoprecipitation (RIPA), radioimmunoassay (RIA) and Western blot (WB), or on the detection of viral genome with molecular assays (e.g., polymerase chain reaction (PCR), real time PCR (qPCR)) and virus isolation in cell cultures [17]. Viral capsid and matrix proteins (p25CA, p28CA, p14NC and p16MA), and envelope glycoproteins (gp135SU, gp46TM) coded by the gag and env genes, respectively, are commonly used as antigens for the detection of SRLV-specific antibodies, whereas long terminal repeats (LTRs) of proviral DNA, and conserved regions in the pol, gag and env genes are used as targets for primers used in molecular assays [6,18,19].

Lack of a "gold standard" assay for the early diagnosis of SRLVs infections, has led to various types and combinations of serological and molecular assays being utilized in eradication programs around the world with variable efficacy [20-30]. The limited success of the currently applied programs to control the disease implies that some of the infected animals evade diagnosis acting as virus reservoirs for the establishment of re-infections. This situation perpetuates the economic impact of SRLVs infections, increases the uncertainty and the cost of the invested resources for SRLVs eradication, and last but not least, reduces the willingness of farmers to participate in control programs.

Currently, universally applicable diagnostic tools are not available, and the development of highly sensitive and specific diagnostic protocol is a priority. Development of efficient diagnostic tools is a challenging task due to (i) the genetic variability of SRLVs associated with mutations, recombination and cross-species transmission, and (ii) the peculiarities of small ruminants' humoral immune response regarding late seroconversion, intermittent and epitope-specific antibody production. The objectives of this review paper were to summarize the available diagnostic assays and methods routinely used in SRLVs control programs emphasizing on their applications, advantages, and drawbacks, and to describe and discuss current and future perspectives, challenges, limitations and impacts regarding the development of reliable and efficient diagnostic tools for SRLVs.

\section{Diagnosis of Small Ruminant Lentiviral Infection}

\subsection{Serological Methods}

2.1.1. Agar Gel Immunodiffusion (AGID)

AGID test had been previously recommended from the OIE as the method of choice for SRLVs routine screening for animal trading and eradication programs against MV and CAE [18]. However, after the validation and wide application of commercial ELISAs, AGID test has been used mainly as a confirmatory test rather than screening purposes $[1,27]$. More precisely, two AGID tests were used in voluntary national MV control program in Finland (AGID kit Institut Pourquier MV / CAEV for screening, and AGID Maeditect 1000, Central Veterinary Laboratory, UK for confirmation of positive samples) [23] and AGID kit Maeditect (Veterinary Laboratories Agency, Weybridge, UK) has been used initially as screening test and later as confirmatory test in ELISA positive samples (CAEV/MAEDIVISNA kit, Institut Pourquier, Montpellier, France) in control program in Norway [31,32]. Similarly, in UK control programs, Maeditect and Capriclear AGID tests (Central Veterinary Laboratory, Weybridge, UK) have been used as initial diagnostic methods due to their high specificity, followed by indirect ELISA Elitest MVV/CAEV (Hyphen BioMed, Neuville-sur- 
Oise, France) as routine screening assays to improve sensitivity [22]. The most commonly used antigens in AGID tests are the MVV p25 or the CAEV p28 capsid antigen (CA) and the envelope glycoprotein gp135 (SU) obtained from cell culture supernatants infected with certain viral strains (e.g., CAEV-63 and MVV WLC1) [17-19]. The performance of AGID test depends mainly on viral strains and specific viral antigens used, as agar gel precipitation requires multiple binding sites between antibodies and viral epitopes $[17,19]$. In goats, AGID sensitivity ranges from 56.0 to $92.0 \%$ and the specificity is $100.0 \%$, whereas the respective values in sheep range from 76.3 to $99.3 \%$ and from 98.3 to $99.4 \%$ depending on the viral antigens and the confirmatory methods utilized [17-19]. Although cross-reactivity has been reported [27], the partially conserved epitopes among MV and CAE viral strains and the different immune responses of sheep and goats regarding immunodominant epitopes hinders the robust interaction of antibodies with the selected epitopes [17,19]. In addition, the combination of viral antigens may lead to higher sensitivity, since the humoral immune response fluctuates depending on the infection stage; antibodies against gp135 are predominant in chronically infected animals, whereas antibodies against capsid antigens (p28/p25) are present during the early infection stages $[17,27,33]$. Although commercial AGID kits are available (e.g., Maeditect kit, APHA Scientific, Addlestone, Surrey, United Kingdom; AGID CAEV P28, IDEXX, Westbrook, ME, USA) [27], the use of local strains can further improve the diagnostic performance of the method; however, this approach is laborious and increases the cost [19], as it requires costly equipment and consumables for the propagation of the virus in cell cultures. Furthermore, AGID is time-consuming, as the results are usually read after a $24-48$-h incubation, and specialized personnel is required to visually interpret precipitin lines formed in the agar gel. Moreover, AGID's low sensitivity does not favor its widespread use as a routine screening method [1,18,19,34]. On the other hand, its high specificity enhances its use as a confirmatory test (especially for ELISAs).

\subsubsection{Enzyme-Linked Immunosorbent Assay (ELISA)}

ELISAs have been widely exploited in SRLVs control programs for the screening of sheep and goat populations. For example, in MVV control program in Aragón of Spain sheep serum samples have been tested by ELISA Elitest MVV/CAEV (Hyphen BioMed, Neuville-sur-Oise, France) [24], whereas in Dutch national MVV control program a complex-trapping blocking (CTB) ELISA of specific epitopes on p28 capsid protein has been exploited [35]; in compulsory CAEV eradication program in South Tyrol of Italy, ELISA CAEV/MAEDI-VISNA kit of Institut Pourquier (Montpellier, France) has been used from 2007 until 2011, before its replacement by ELISA IDEXX MVV/CAEV p28 Ab Screening Test (IDEXX, France) [36], whereas ELISA kit CAEV/MVV Total Ab (Idexx Switzerland AG, Liebefeld-Bern, Switzerland), and a home-made surface subunit SU5 peptides ELISA have been used as a screening method and a predictor of lentiviruses subtypes, respectively, in Swiss CAEV eradication program [37-40]. Despite the fact that its performance is not universally constant, ELISA remains a user-friendly, low-cost, semiquantitative diagnostic test, with sufficient repeatability and, in most cases, sensitivity and specificity $[18,34]$. Both the commercially available kits (see Table 1 ) and in-house assays belong either to the indirect or to the competitive assay type for the detection of circulating antibodies in infected animals. In the indirect ELISA assays, antigens can be the whole virus, recombinant proteins, or synthetic peptides, whereas in the competitive assays, combinations of monoclonal antibodies are utilized for competition with sera antibodies for the coated viral antigens. Although ELISA is the most commonly used diagnostic test, scarcity of efficient validation protocols using at least one reference standard method (RIPA, or WB), according to the guidelines of OIE [17], constitutes the major flaw in the process of being officially recognized as valid and reliable screening assays. Although many ELISAs have been tested and reported for SRLVs detection [18], only a few have been validated for their high sensitivity compared to reference methods [17,19]; namely, (i) an indirect whole virus (OLV 130/91 strain) ELISA and a recombinant transmembrane (r-TM) ELISA (strain K1514) compared to AGID test (OLV 130/91 strain) and WB in sheep samples [41], (ii) an 
indirect whole virus (Canadian CAEV strain) ELISA compared to AGID test, WB and fixedcell fluorescent antibody test in goat samples [42], (iii) the competitive ELISA CAEV-63 SU (surface envelope SU of the 79-63 CAEV isolate) of VMRD inc. compared to RIPA in sheep and goat samples [43,44], and (iv) the competitive CTB ELISA of Dutch control program has been validated against CAEV-63 AGID and ZZV1050 AGID tests for goat and sheep samples, respectively [45]. Only one indirect ELISA with capsid (CA) and transmembrane (TM) peptides (Elitest-MVV, HYPHEN Biomed, Neuville-sur-Oise, France and Pourquier) has been validated compared to OPPV WLC1 AGID test in sheep samples, according to OIE criteria $[19,46]$. In any case, for the objective assessment of its sensitivity, validation of an ELISA test should be conducted against reference sera standards with viral antigens of similar or variable strains coated on the ELISA plates. A considerable advantage of ELISAs when compared to other serological methods is the capability to be applied in various biological samples such as blood serum and plasma, and milk [47-53]. Among these samples, milk seems to be the most ambiguous sample matrix given that several factors may adversely affect the reliable diagnosis, such as the progressive reduction of antibodies throughout the lactation, the occurrence of false positive background signals in cases of mastitis, colostrum, increased milk fat content or even the specific immune response of the mammary gland depending on the infection stage [47,52]. ELISAs fluctuate between high sensitivity and low specificity and vice versa; for example, high sensitivity of competitive ELISAs due to the use of undiluted sera is usually combined by low specificity $[19,43]$. In general, the unsatisfactory diagnostic performance of ELISAs are mainly attributed to: (i) the unfavorable combination of antigen used in the test with the infection stage, as the production of antibodies against matrix and capsid proteins (e.g., p25, p28, and p16) during early infection stages precedes the production of other antibodies; on the contrary they are almost eliminated at later stages in the infected animals, where antibodies against gp46 and gp135 prevail [27,54-56], (ii) the antigenic distance between the viral strain used in the development of the assay and the infecting strain of the examined animals; although SRLVs are characterized by cross-reactivity [57,58], homologous humoral immune response in strain-specific epitopes reduces dramatically the sensitivity of ELISA test and therefore, leads to misdiagnosis $[37,54,59,60]$, (iii) the late seroconversion of animals, the fluctuation of antibody response during animal's life and the alternations between viremia and humoral immune responses $[15,18,52,61]$, and (iv) the animal species; in goats, for example, a more robust reactivity against transmembrane glycoproteins compared to capsid proteins has been observed [37,55]. Therefore, except for the impediments arising from virus nature and the immunopathological mechanisms, a critical endeavor for the enhancement of serological diagnosis performance is to enrich the antigenic design of ELISA and improve its negative predictive value. The use of whole virus, incorporation of multiple antigens and synthetic peptide combinations, and genotype-specific immunodominant epitopes have been proposed for the extension of the antigenic spectrum and the amplification of the detection capacity of the assay $[54,56-58,60,62,63]$. 
Table 1. Commercially available ELISA kits used for the diagnosis of SRLV infections.

\begin{tabular}{|c|c|c|c|c|c|c|}
\hline Commercial Kit Product Name & ELISA Format & Antigen & $\begin{array}{c}\text { Sample/ } \\
\text { Diagnostic Matrix }\end{array}$ & $\mathrm{Se} / \mathrm{Sp}$ & Reference Test & Ref \\
\hline $\begin{array}{l}\text { LSIVet }^{\mathrm{TM}} \text { Ruminant Maedi-Visna/CAEV } \\
\text { serum ELISA kit (LSI, Thermo Fisher } \\
\text { Scientific, Waltham, MA, USA) }\end{array}$ & Competitive & gp135 TM protein/A and B genotypes & Serum & $\begin{array}{r}90.2 \% \mathrm{a}^{\mathrm{a}} / 92.8 \% \mathrm{~m}^{\mathrm{a}} \\
100.0 \% \mathrm{~m}^{\mathrm{b}} / 85.7 \% \mathrm{~b}^{\mathrm{b}}\end{array}$ & qPCR & [27] \\
\hline $\begin{array}{l}\text { ID screen }{ }^{\circledR} \text { MVV/CAEV indirect (IDvet } \\
\text { Innovative Diagnostics, Grabels, France) }\end{array}$ & Indirect & $\begin{array}{l}\text { peptides from the MVV/CAEV, gp135 } \\
\text { and p25 proteins/A, B and E } \\
\text { genotypes }\end{array}$ & Serum, plasma and milk & $\begin{array}{c}100.0 \% \text { a } / 97.8 \% \%^{\mathrm{a}} \\
91.7-100.0 \%{ }^{\mathrm{b}} / 97.6-98.9 \% \mathrm{~b}\end{array}$ & $\begin{array}{l}\text { qPCR, } \\
\text { ELISA }{ }^{A, B}\end{array}$ & {$[27,64]$} \\
\hline $\begin{array}{c}\text { Eradikit }^{\mathrm{TM}} \text { SRLV screening test (IN3 } \\
\text { diagnostic, Italia) }\end{array}$ & Indirect & $\begin{array}{c}g a g \text { and } e n v \text { peptides / A, B and E } \\
\text { genotypes }\end{array}$ & Serum, plasma and milk & $\begin{array}{c}96.1 \%^{\mathrm{a}} / 99.4 \%^{\mathrm{a}} \\
100.0 \%^{\mathrm{b}} / 94.6 \% \mathrm{~m}^{\mathrm{b}}\end{array}$ & $\mathrm{qPCR}$ & [27] \\
\hline $\begin{array}{l}\text { Elitest MVV/CAEV (Hyphen BioMed, } \\
\text { Neuville-sur-Oise, France) or Innotest } \\
\text { MVV (Innogenetics, Gent, Belgium) }\end{array}$ & Indirect & $\begin{array}{l}\text { MVV capsid rp25 and gp46 TM } \\
\text { protein/EV-1 strain, A genotype }\end{array}$ & Serum & $\begin{array}{c}98.0,96.9,97.8,99.3 \% \text { a } / 94.7 \\
99.2,98.2,99.4 \% \text { a } \\
95.8 \% \mathrm{~b} / 99.7 \% \mathrm{~b}\end{array}$ & $\begin{array}{c}\text { qPCR, } \\
\text { Bayesian analysis, AGID } \\
\text { and WB }\end{array}$ & {$[27,32,46,65]$} \\
\hline $\begin{array}{l}\text { MVV/CAEV p28 Ab Screening Test } \\
\text { (Idexx, Westbrook, ME, USA) }\end{array}$ & Indirect & $\begin{array}{l}\text { peptide of TM protein (env gene) and } \\
\text { of the recombinant p28 capsid } \\
\text { protein/A genotype }\end{array}$ & Serum and plasma & $\begin{array}{c}84.3 \%^{\mathrm{a}} / 99.6 \%^{\mathrm{a}} \\
91.7 \% \mathrm{~m}^{\mathrm{b}} / 100.0 \%^{\mathrm{b}}\end{array}$ & qPCR & [27] \\
\hline $\begin{array}{c}\text { ELISA MAEDI } \\
\text { VISNA/CAEV (Institut Pourquier, } \\
\text { Montpellier, France) * }\end{array}$ & Indirect & $\begin{array}{l}\text { recombinant p28 gag protein and } \\
\text { peptide of the env protein (gp135)/A } \\
\text { genotype }\end{array}$ & Serum & $98 \%^{\mathrm{a}} / 97.4 \%^{\mathrm{a}}$ & Bayesian analysis & [32] \\
\hline $\begin{array}{c}\text { CAEV/MVV Total Ab Test (Idexx, } \\
\text { Westbrook, ME, USA) or Checkit } \\
\text { CAEV/MVV (Dr. Bommeli } \\
\text { AG, Bern, Switzerland) }\end{array}$ & Indirect & Whole virus/strain OLV, A gentoype & Serum, plasma and milk & $\begin{array}{l}98.6 \%^{\mathrm{b}} / 99.3 \%^{\mathrm{b}} \\
91.4 \%^{\mathrm{c}} / 98.9 \%^{\mathrm{c}}\end{array}$ & GAG-GST ELISA ** & [66] \\
\hline $\begin{array}{l}\text { Small Ruminant Lentivirus Antibody } \\
\text { Test Kit, cELISA } \\
\text { (VMRD, Pullman, WA, USA) }\end{array}$ & Competitive & SU Antigen of gp135/B genotype & Serum & $\begin{array}{l}98.6 \%^{\mathrm{a}} / 96.9 \%^{\mathrm{a}} \\
100 \% \mathrm{~b}^{\mathrm{b}} / 96.4 \%^{\mathrm{b}}\end{array}$ & RIPA & {$[43,44]$} \\
\hline $\begin{array}{c}\text { INgezim } \\
\text { Maedi screening } \\
\text { Technologies, Spain) }\end{array}$ & Indirect & $\begin{array}{l}\text { synthetic peptides from the env } \\
\text { protein/A and B genotypes }\end{array}$ & Serum & No published data & & \\
\hline $\begin{array}{l}\text { Enferplex Goat/Sheep Multi-Disease 5D } \\
\text { (Enfer Scientific, Co. Kildare, Ireland) }\end{array}$ & Indirect & $\begin{array}{l}\text { recombinant p25 core protein, TM1 } \\
\text { gp46 synthetic peptide }\end{array}$ & Serum, plasma and milk & No published data & & \\
\hline
\end{tabular}

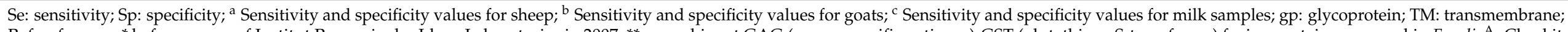

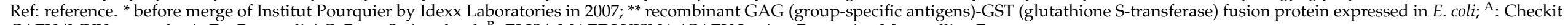
CAEV/MVV monophasic Dr. Bommeli AG, Bern, Switzerland; ' : ELISA MAEDI VISNA/CAEV Institut Pourquier, Montpellier, France. 


\subsubsection{Other Serological Methods}

RIPA, RIA and WB are usually used as "gold standard" methods. RIPA and RIA rely on the conformation of antibody-epitope complexes like in the AGID method; however, in these assays, the antigens (RIPA) and the antibodies (RIA) are ${ }^{35} \mathrm{~S}$-labelled, increasing their sensitivity $[19,67]$. WB uses viral antigens, usually whole virus, which are separated in reducing sodium dodecyl sulfate polyacrylamide electrophoresis gels (SDS PAGE gels), transferred to nitrocellulose membranes and subsequently incubated with animal sera that potentially contain antibodies that recognize and bind to the separated viral antigens [19,34]. The denaturing conditions of WB instead of the native conditions in RIPA and AGID, favor the detection of specific antibodies binding to linear epitopes of CA, MA and TM proteins $[19,39]$. Despite their high sensitivity and specificity, RIPA, RIA and WB are not suitable for use in large-scale surveillance programs, but they are rather exploited as reference tests, since they are costly and time-consuming assays applied in specialized diagnostic laboratories by trained staff $[18,49]$. However, a WB technique (MVV strain ZZV 1050) has been used in the national MV control programs in the Netherlands and in Switzerland as confirmatory method of ELISA positive samples [35,39]. Nevertheless, the use of RIPA, RIA and WB for the validation of new diagnostic tests or for the confirmation of ELISA results, should not be considered a priori infallible, as both false positive results (due to nonspecific cross-reactivity) or false negative (due to weak affinity of circulating antibodies for epitopes of viral antigens) have been reported [18].

\subsection{Molecular Methods}

\subsubsection{PCR}

SRLV proviral DNA can be detected in samples of peripheral blood mononuclear cells, colostrum and milk, bronchoalveolar fluid and lungs, mammary gland, carpal synovial membranes, brain, and other secondary tissue targets such as bone marrow, spleen, lymph nodes, testicles, ovaries, uterus, heart, kidneys and liver $[19,47,48,51,52,56,61,68-74]$. The presence of SRLV genetic material has been, also, reported in air and water samples collected from sheep farms, highlighting the potential for horizontal transmission of SRLVs [75]. After the development of the first successful PCR protocol applied for the detection of CAEV and MVV [76], remarkable progress has been made resulting in more sophisticated and reliable molecular diagnostic protocols. Except for the conventional PCR, other PCR techniques have been developed to improve the sensitivity, specificity and accuracy of molecular diagnostics. Indeed, combination of PCRs for different genomic regions, multiplex PCRs, (semi-)nested PCRs, and real-time PCRs have been exploited with contradictory results. The diagnostic performances of some of the PCR techniques used for SRLVs detection are summarized in Table 2. Primer sequences can be found in detail in supplementary material (Table S1). 
Table 2. PCR techniques and information regarding primers, detected strains, animal species, country and diagnostic performance.

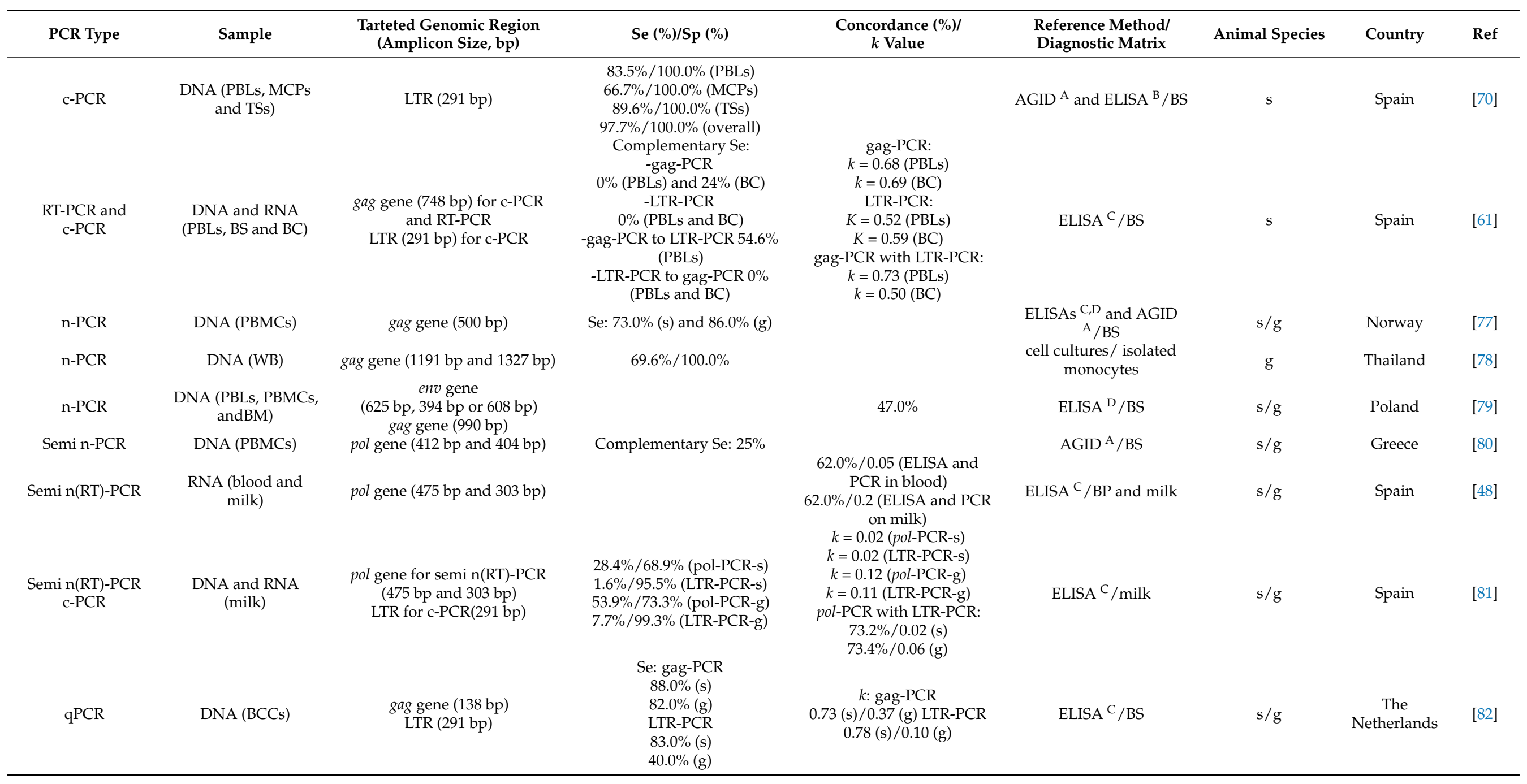


Table 2. Cont.

\begin{tabular}{|c|c|c|c|c|c|c|c|c|}
\hline PCR Type & Sample & $\begin{array}{l}\text { Tarteted Genomic Region } \\
\text { (Amplicon Size, bp) }\end{array}$ & Se $(\%) / S p(\%)$ & $\begin{array}{c}\text { Concordance }(\%) / \\
k \text { Value }\end{array}$ & $\begin{array}{l}\text { Reference Method/ } \\
\text { Diagnostic Matrix }\end{array}$ & Animal Species & Country & Ref \\
\hline qPCR & $\begin{array}{c}\text { DNA (BCCs and } \\
\text { MCPs) }\end{array}$ & $\begin{array}{l}\text { gag gene (138 bp) } \\
\text { LTR (291 bp) }\end{array}$ & $\begin{array}{c}\text { LTR-PCR: } \\
\text { 21.0\%/- (BCCs-g) } \\
50.0 \% / 94.0 \% \text { (MCPs-g) } \\
82.0 \% / 80.0 \% \text { (BCCs-s) } \\
70.0 \% / 99.0 \% \text { (MCPs-s) } \\
\text { gag-PCR: } \\
\text { 39.0\%/- (BCCs-g) } \\
61.0 \% / 88.0 \% \text { (MCPs-g) } \\
89.0 \% / 81.0 \% \text { (BCCs-s) } \\
89.0 \% / 89.0 \% \text { (MCPs-s) }\end{array}$ & $\begin{array}{c}\text { between PCRs: } \\
\text { 77.0\%/0.45 (BCCs-g) } \\
83.0 \% / 0.63 \text { (BCCs-s) } \\
87.0 \% / 0.76 \text { (MCPs-g) } \\
87.0 \% / 0.75 \text { (MCPs-s) } \\
\text { 90.0\%/0.76 (MCPS of bulk } \\
\text { milk-g) }\end{array}$ & ELISA $^{\mathrm{C}} / \mathrm{BS}$ & $\mathrm{s} / \mathrm{g}$ & $\begin{array}{l}\text { The } \\
\text { Netherlands }\end{array}$ & [49] \\
\hline qPCR & DNA (PBLs) & $\begin{array}{l}\text { gagMA (113 bp) } \\
\text { LTR (101 bp) }\end{array}$ & $\begin{array}{c}\text { Se: } \\
\text { 89.9\% (gagMA-PCR) } \\
80.2 \% \text { (LTR-PCR) } \\
79.0 \% \text { (overall) } \\
\text { 88.0\%/100.0\% (PBLs-s) }\end{array}$ & $k=0.72$ & ELISA $^{\mathrm{E}} / \mathrm{BS}$ & $\mathrm{s} / \mathrm{g}$ & Slovenia & [83] \\
\hline qPCR & DNA(PBLs and BC) & gag gene (524 bp) & $\begin{array}{c}83.3 \% / 100.0 \% \text { (PBLs-g) } \\
63.0 \% / 100.0 \% \text { (blood clot-s) } \\
21.0 \% / 100.0 \% \text { (blood clot-g) } \\
75.0 \% / 100.0 \% \text { (blood clot-s) } \\
25.0 \% / 100.0 \% \text { (blood clot-g) }\end{array}$ & & $\begin{array}{c}\text { ELISA } \mathrm{C}, \mathrm{F}, \mathrm{G}, \mathrm{H}, \mathrm{I} \text { and AGID } \\
\mathrm{J} / \mathrm{BS} \\
\mathrm{qPCR} \text { in PBLs }\end{array}$ & $\mathrm{s} / \mathrm{g}$ & Belgium & [27] \\
\hline Semi n-qPCR & DNA (PBLs) & pol gene ( $455 \mathrm{bp}$ and $416 \mathrm{bp}$ ) & $\begin{array}{c}\text { Se: } 86.0 \% \\
\text { Relative Se: } 28.0 \%\end{array}$ & $79.0 \% / 0.58$ & ELISA $^{\mathrm{G}} / \mathrm{BP}$ & $\mathrm{s} / \mathrm{g}$ & Greece & [84] \\
\hline $\mathrm{q}(\mathrm{RT})-\mathrm{PCR}$ & $\begin{array}{l}\text { DNA (WB) and RNA } \\
\text { (WB and BS) }\end{array}$ & env gene (114 bp) & $\begin{array}{c}\text { qPCR: } 83.3 \% / 87.5 \% \\
\text { RT qPCR: } 58.3 \% / 66.6 \%\end{array}$ & & ELISA $^{\mathrm{D}, \mathrm{E} / \mathrm{BS}}$ & $\mathrm{s} / \mathrm{g}$ & Italy & [85] \\
\hline $\mathrm{q}(\mathrm{RT})-\mathrm{PCR}$ & $\begin{array}{l}\text { DNA and RNA } \\
\text { (PBLs and lung } \\
\text { samples) }\end{array}$ & gag gene (524 bp) & $\begin{array}{l}86.7 \% / 80.0 \% \\
60.9 \% / 75.0 \%\end{array}$ & $\begin{array}{l}87.0 \% \\
61.0 \%\end{array}$ & $\mathrm{AGID}^{\mathrm{A}} / \mathrm{BS}$ ELISA ${ }^{\mathrm{C}} / \mathrm{BS}$ & $\mathrm{s} / \mathrm{g}$ & Belgium & [86] \\
\hline
\end{tabular}

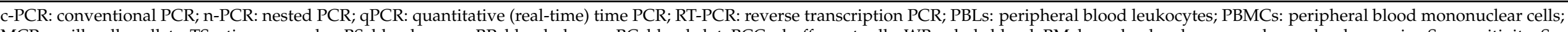

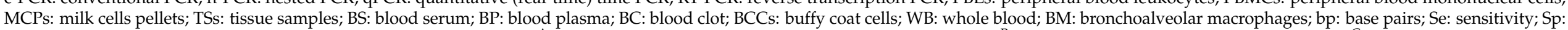

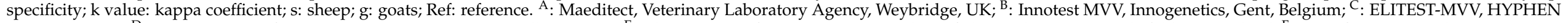

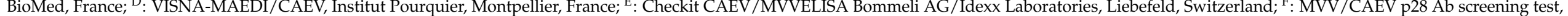

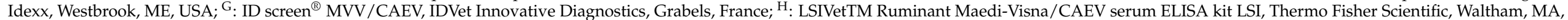
USA; ${ }^{\text {I: }}$ Eradikit ${ }^{\mathrm{TM}}$ SRLV, IN3 diagnostic, Italia; ${ }^{\mathrm{J}}$ : AGID CAEV P28 kit, Idexx, Westbrook, ME, USA 
For the application of PCR, DNA extracted mainly from peripheral blood leucocytes (PBLs) or mononuclear cells (PBMCs) or milk cells is used, while DNA extracted from tissues is less frequently utilized for confirmatory purposes; the possibility of detecting viral RNA by applying reverse transcription PCR is null, as circulating cell-free virions are usually non-detectable; however, it could be used to study horizontal virus transmission $[19,34,61]$. On a routine basis, DNA (genomic or/and episomal) is extracted either by commercial kits or via in-house methods from PBLs or PBMCs as monocytes/macrophages and dendritic cells are the only cells known to support replication of SRLVs. Major determinants for the selection of a DNA-extraction protocol are the time required, yield and quality of the extracted DNA [87]. In addition, a commercial qPCR kit (EXOone Maedi Visna CAEV oneMix, Exopol, Spain) is available for the diagnosis of SRLVs genotypes A, $\mathrm{B}$, and $\mathrm{E}$ exhibiting higher sensitivity from serological methods and home-made gag PCR in diagnosis in field samples [63]. The major advantage of PCR technologies compared to the serological methods is the early detection of the SRLVs infection, preceding the production of antibodies which may occur months or years later [2]. Nonetheless, low viral load of infected animals may hinder the detection of proviral DNA resulting in false negative results and reduced sensitivity [67]. Decreased viral load is indicative of low number of infected monocytes $[5,88]$ or restricted viral replication due to humoral immune response which probably acts protective for the infected animals [5,52,61]. Moreover, the high mutation rate of SRLVs due to the low fidelity of the virion's reverse transcriptase and the frequently observed recombinations $[1,89]$ undermine the diagnostic performance of PCR. To achieve sufficient specificity, the primers have to be designed for conserved regions of the viral genome, avoiding the env gene which is less conserved among genotypes $[18,90]$. On the other hand, the problem of virus genetic variability can be mitigated by the use of degenerate primers expanding the detection range and improving the sensitivity of the method $[80,84,91]$. In infected animals, false negative results of PCR could be linked to co-existence of multiple SRLVs mutants in an infected population. Although the development of universally applicable PCR assays may be extremely difficult due to the aforementioned obstacles, evidence-based modification of the protocols for the detection of local strains could be a realistic target in the field of SRLVs diagnostics. This is a necessary step when planning SRLVs surveillance programs, demanding (i) genotyping, sequencing, and phylogenetic analyses of the relevant strains, (ii) designation of specific and widely applicable primers, and (iii) the development of sensitive and specific PCR protocols with the potential and the capacity to be applied in a specific geographical region (with available specialized laboratory infrastructures, equipment, and staff).

\subsubsection{Other Molecular Assays}

Heteroduplex mobility assay (HMA) usually follows the PCR amplification for the classification of the detected strains in comparison to the reference strains and for the assessment of the homogeneity of strains detected in a region or a flock [79,92-95]. It is a qualitative technique and a valuable tool to study the molecular epidemiology of SRLVs. In addition, loop-mediated isothermal amplification (LAMP) and recombinase polymerase amplification lateral flow dipstick (RPA-LFD) techniques have been lately applied with success for CAEV diagnosis [96-98]. Although results seem promising when compared to "traditional" serological and molecular techniques, more studies are needed for the validation of the diagnostic performance of these innovative techniques in a wider spectrum of viral strains.

\subsection{Cell Cultures}

SRLVs isolation can be achieved through co-cultures of peripheral blood mononuclear cells (PBMCs) with sheep choroid plexus cells or goat synovial membrane cells [17]. The evidence of SRLVs infection is co-evaluated from the existence of a cytopathic effect and a positive reverse transcriptase activity assay [34]. However, the expected cytopathic effect (CPE), which is the formation of syncytia and/or refractile stellate cells with dendritic pro- 
cesses, may be difficult to detect for inexperienced staff with limited training in microscopy and cell biology. In addition, strain variability regarding the extend of detectable CPE cannot be excluded [67]. It is obvious that cell cultures cannot be routinely used for the diagnosis of SRLVs infections given the increased cost, the complexity, the limitations derived from in vitro viral replication, and the demands for specialized laboratory and trained personnel. Therefore, cell cultures are mainly applied either for the verification of the results of other molecular diagnostics or for research purposes in the fields of immunopathology and SRLVs genetics and molecular epidemiology $[33,37,39,99,100]$.

\section{Current and Future Perspectives in Diagnosis of SRLV Infections}

Diagnosis of lentiviral infections constitutes the cornerstone for the successful implementation of eradication programs. A "gold standard" test with high values of sensitivity, specificity and accuracy, blindly used in every case does not seem readily feasible when considering the special characteristics of SRLVs (i.e., high genetic variability, mechanisms of virus replication, and animal humoral immune response). Nonetheless, the scientific community has addressed these limitations, proposing targeted combinations of diagnostic tools, which are constantly evaluated to reduce the possibility of both newly or persistently infected animals to evade diagnosis [27,39,62,63,70,82,86,101,102]. Although combination of diagnostics increases cost, time, and the effort required, it seems to be inevitable for the early and safe diagnosis in young animals which are likely infected but seronegative. However, in lambs early diagnosis may be limited by interference of maternal antibodies or provirus transmitted during suckling or milk aspiration [103].

Genotyping and classification of the circulating SRLVs strains in a specific region/breed could permit the targeted application of appropriate serological and molecular tests. In this direction, combined peptide ELISAs with type-specific epitopes from multiple genotypes could be tested in old and/or symptomatic animals and in mixed flocks (cross-species transmission and recombination) before the design of primers for PCR-based methods. Additionally, diagnostic tools should be adapted in a more animal- and farmer-friendly framework, utilizing biological materials with less invasive sample collection techniques. For example, milk is a promising alternative to blood and in many cases exhibits satisfying concordance with the results obtained from serum and whole blood samples both on serological and PCR assays; however, standardization of milk as sampling matrix and further verification in the field is needed for its use in serological and molecular tests. Particularly, in the case of highly sensitive screening tests, bulk milk samples could be incorporated as SRLVs-status determination tests for the initial characterization of a flock as SRLVs-infected or free. Newly developed technologies used in the HIV diagnosis such as specific antibodyantigen biomarkers or dried-blood spot testing [104] could be exploited in combination with LAMP and RPA-LFD techniques on SRLVs diagnosis for the development of in situ, rapid, user-friendly, cost-effective, and reliable diagnostic tools. In future, point-of-care (POC) testing of small ruminant infectious diseases in mobile platform technologies could integrate SRLVs diagnostic assays contributing to the control and elimination of critical epidemic and endemic diseases, including MV and CAE.

\section{Impact of Early and Efficient SRLVs Diagnosis}

Early and effective diagnosis of SRLVs and subsequently the control of MV and CAE are both critical endeavors for countries with a developed small ruminant farming sector. In addition, until now the applied programs for the eradication of SRLVs have not been scheduled based on a common diagnostic protocol, which allows deviations in the interpretation of requirements for the accreditation of SRLV-free regions and farms. Research on SRLVs diagnostics will form the steppingstone for the surveillance of the disease and the investigation of alternative control strategies. Linking the epidemiological characteristics of the disease with the use of novel and more efficient diagnostic techniques can ensure an integrated approach for the control of the disease in practice. 
The economic impact of SRLVs early diagnosis is likely enormous, as both MV and $\mathrm{CAE}$ are associated with dramatic, direct, and indirect economic losses, which undermine the sustainability of the farms. The magnitude of economic losses caused by the diseases is determined by factors related to their clinical symptoms and epidemiology at the farm level. The effective control of the diseases may drastically reduce monetary losses associated with the detrimental effects on health, welfare, and productivity of animals, while early diagnosis will facilitate for the first time the large-scale production of certified SRLVs-free breeding stocks, enjoying the expected added-value. The enhancement of the economic sustainability of farms will further facilitate the development of the sector and the eligibility of the small ruminant farming profession. It will also contribute to the survival of farmers in the provinces, particularly in disadvantaged and remote areas, where livestock farming is one of the most important, main, or complementary sources of income. Moreover, animal health and welfare status will be significantly improved via early diagnosis of SRLV infections, and the requirement for safe products of animal origin, produced by healthy animals that live "a life worth living", will be satisfied.

Supplementary Materials: The following are available online at https:/ /www.mdpi.com/article/ 10.3390/v13091711/s1, Table S1: Primer sequences of PCR techniques referred in Table 2.

Author Contributions: Conceptualization, I.B., A.I.G. and A.I.K.; writing-original draft preparation, A.I.K., I.S. and A.I.G.; writing-review and editing, S.C.C., A.I.G. and I.B.; supervision, A.I.G. All authors have read and agreed to the published version of the manuscript.

Funding: The research work was supported by the Hellenic Foundation for Research and Innovation (H.F.R.I.) under the "First Call for H.F.R.I. Research Projects to support Faculty members and Researchers and the procurement of high-cost research equipment grant" (Project Number: HFRI-FM17-1083).

Conflicts of Interest: None of the authors of this paper has a financial or personal relationship with other people or organizations that could inappropriately influence or bias the content of the paper.

\section{References}

1. Minguijón, E.; Reina, R.; Pérez, M.; Polledo, L.; Villoria, M.; Ramírez, H.; Leginagoikoa, I.; Badiola, J.J.; García-Marín, J.F.; de Andrés, D.; et al. Small ruminant lentivirus infections and diseases. Vet. Microbiol. 2015, 181, 75-89. [CrossRef]

2. Ramírez, H.; Reina, R.; Amorena, B.; de Andrés, D.; Martínez, H.A. Small ruminant Lentiviruses: Genetic variability, tropism and diagnosis. Viruses 2013, 5, 1175-1207, ISBN 5255562319. [CrossRef] [PubMed]

3. Molaee, V.; Bazzucchi, M.; De Mia, G.M.; Otarod, V.; Abdollahi, D.; Rosati, S.; Lühken, G. Phylogenetic analysis of small ruminant lentiviruses in Germany and Iran suggests their expansion with domestic sheep. Sci. Rep. 2020, 10, 2243. [CrossRef]

4. Michiels, R.; Adjadj, N.R.; De Regge, N. Phylogenetic analysis of belgian small ruminant lentiviruses supports cross species virus transmission and identifies new subtype B5 strains. Pathogens 2020, 9, 1-13. [CrossRef] [PubMed]

5. Blacklaws, B.A. Small ruminant lentiviruses: Immunopathogenesis of visna-maedi and caprine arthritis and encephalitis virus. Comp. Immunol. Microbiol. Infect. Dis. 2012, 35, 259-269. [CrossRef]

6. Gomez-Lucia, E.; Barquero, N.; Domenech, A. Maedi-Visna virus: Current perspectives. Vet. Med. Res. Rep. 2018, 9, 11-21. [CrossRef] [PubMed]

7. Gayo, E.; Polledo, L.; Balseiro, A.; Martínez, C.P.; García Iglesias, M.J.; Preziuso, S.; Rossi, G.; García Marín, J.F. Inflammatory Lesion Patterns in Target Organs of Visna/Maedi in Sheep and their Significance in the Pathogenesis and Diagnosis of the Infection. J. Comp. Pathol. 2018, 159, 49-56. [CrossRef]

8. Blacklaws, B.A.; Berriatua, E.; Torsteinsdottir, S.; Watt, N.J.; De Andres, D.; Klein, D.; Harkiss, G.D. Transmission of small ruminant lentiviruses. Vet. Microbiol. 2004, 101, 199-208. [CrossRef] [PubMed]

9. Pisoni, G.; Bertoni, G.; Manarolla, G.; Vogt, H.R.; Scaccabarozzi, L.; Locatelli, C.; Moroni, P. Genetic analysis of small ruminant lentiviruses following lactogenic transmission. Virology 2010, 407, 91-99. [CrossRef] [PubMed]

10. Illius, A.W.; Lievaart-Peterson, K.; McNeilly, T.N.; Savill, N.J. Epidemiology and control of maedi-visna virus: Curing the flock. PLoS ONE 2020, 15, e238781. [CrossRef]

11. Broughton-Neiswanger, L.E.; White, S.N.; Knowles, D.P.; Mousel, M.R.; Lewis, G.S.; Herndon, D.R.; Herrmann-Hoesing, L.M. Non-maternal transmission is the major mode of ovine lentivirus transmission in a ewe flock: A molecular epidemiology study. Infect. Genet. Evol. 2010, 10, 998-1007. [CrossRef] [PubMed]

12. Araújo, J.F.; Andrioli, A.; Pinheiro, R.R.; Sider, L.H.; de Sousa, A.L.M.; de Azevedo, D.A.A.; Peixoto, R.M.; Lima, A.M.C.; Damasceno, E.M.; Souza, S.C.R.; et al. Vertical transmissibility of small ruminant lentivirus. PLoS ONE 2020, 15, e0239916. [CrossRef] 
13. Cortez-Romero, C.; Pellerin, J.L.; Ali-Al-Ahmad, M.Z.; Chebloune, Y.; Gallegos-Sánchez, J.; Lamara, A.; Pépin, M.; Fieni, F. The risk of small ruminant lentivirus (SRLV) transmission with reproductive biotechnologies: State-of-the-art review. Theriogenology 2013, 79, 1-9. [CrossRef]

14. Benavides, J.; Fuertes, M.; García-Pariente, C.; Otaola, J.; Delgado, L.; Giraldez, J.; García Marín, J.F.; Carmen Ferreras, M.; Pérez, V. Impact of maedi-visna in intensively managed dairy sheep. Vet. J. 2013, 197, 607-612. [CrossRef]

15. Kalogianni, A.I.; Bossis, I.; Ekateriniadou, L.V.; Gelasakis, A.I. Etiology, Epizootiology and Control of Maedi-Visna in Dairy Sheep: A Review. Animals 2020, 10, 1-15. [CrossRef] [PubMed]

16. Nowicka, D.; Czopowicz, M.; Bagnicka, E.; Rzewuska, M.; Strzałkowska, N.; Kaba, J. Influence of small ruminant lentivirus infection on cheese yield in goats. J. Dairy Res. 2015, 82, 102-106. [CrossRef]

17. OIE. Chapter 3.7.2-Caprine arthritis/encephalitis \& Maedi-visna. In OIE Terrestrial Manual 2018; OIE: Paris, France, 2018; pp. $1420-1429$.

18. De Andrés, D.; Klein, D.; Watt, N.J.; Berriatua, E.; Torsteinsdottir, S.; Blacklaws, B.A.; Harkiss, G.D. Diagnostic tests for small ruminant lentiviruses. Vet. Microbiol. 2005, 107, 49-62. [CrossRef]

19. Herrmann-Hoesing, L.M. Diagnostic assays used to control small ruminant lentiviruses. J. Vet. Diagnostic Investig. 2010, 22, 843-855. [CrossRef]

20. Polledo, L.; González, J.; Fernández, C.; Miguélez, J.; Martínez-Fernández, B.; Morales, S.; Ferreras, M.C.; Marín, J.F.G. Simple control strategy to reduce the level of Maedi-Visna infection in sheep flocks with high prevalence values ( $>90 \%)$. Small Rumin. Res. 2013, 112, 224-229. [CrossRef]

21. Modolo, J.R.; Stachissini, A.V.M.; Padovani, C.R.; Araujo, J.P.; Castro, R.S.; Ravazzolo, A.P.; Leite, B.L.S. PCR associated with agar gel immunodiffusion assay improve caprine arthritis-encephalitis (CAEV) control. Small Rumin. Res. 2009, 81, 18-20. [CrossRef]

22. Synge, B.A.; Ritchie, C.M. Elimination of small ruminant lentivirus infection from sheep flocks and goat herds aided by health schemes in Great Britain. Vet. Rec. 2010, 167, 739-743. [CrossRef]

23. Sihvonen, L.; Nuotio, L.; Rikula, U.; Hirvelä-Koski, V.; Kokkonen, U.M. Preventing the spread of maedi-visna in sheep through a voluntary control programme in Finland. Prev. Vet. Med. 2000, 47, 213-220. [CrossRef]

24. Pérez, M.; Biescas, E.; de Andrés, X.; Leginagoikoa, I.; Salazar, E.; Berriatua, E.; Reina, R.; Bolea, R.; de Andrés, D.; Juste, R.A.; et al Visna/maedi virus serology in sheep: Survey, risk factors and implementation of a successful control programme in Aragón (Spain). Vet. J. 2010, 186, 221-225. [CrossRef] [PubMed]

25. Cirone, F.; Maggiolino, A.; Cirilli, M.; Sposato, A.; De Palo, P.; Ciappetta, G.; Pratelli, A. Small ruminant lentiviruses in goats in southern Italy: Serological evidence, risk factors and implementation of control programs. Vet. Microbiol. 2019, 228, 143-146. [CrossRef]

26. Pérez, M.; Muñoz, J.A.; Biescas, E.; Salazar, E.; Bolea, R.; de Andrés, D.; Amorena, B.; Badiola, J.J.; Reina, R.; Luján, L. Successful Visna/maedi control in a highly infected ovine dairy flock using serologic segregation and management strategies. Prev. Vet. Med. 2013, 112, 423-427. [CrossRef] [PubMed]

27. Michiels, R.; Van Mael, E.; Quinet, C.; Adjadj, N.R.; Cay, A.B.; De Regge, N. Comparative analysis of different serological and molecular tests for the detection of small ruminant lentiviruses (Srlvs) in Belgian sheep and goats. Viruses 2018, 10, 8-10. [CrossRef]

28. Nord, K.; Løken, T.; Orten, Å. Control of caprine arthritis-encephalitis virus infection in three Norwegian goat herds. Small Rumin. Res. 1998, 28, 109-114. [CrossRef]

29. Kaba, J.; Bagnicka, E.; Czopowicz, M.; Nowicki, M.; Witkowski, L.; Szaluoe-Jordanow, O. Long-term study on the spread of caprine arthritis-encephalitis in a goat herd. Cent. J. Immunol. 2011, 36, 170-173.

30. Peterhans, E.; Greenland, T.; Badiola, J.; Harkiss, G.; Bertoni, G.; Amorena, B.; Eliaszewicz, M.; Juste, R.A.; Kraßnig, R.; Lafont, J.-P.; et al. Routes of transmission and consequences of small ruminant lentiviruses (SRLVs) infection and eradication schemes. Vet. Res. 2004, 35, 257-274. [CrossRef]

31. Kampen, A.H.; Tharaldsen, J.; Mork, J.; Grøneng, G. Surveillance and Control Programmes for Terrestrial and Aquatic Animals in Norway; National Veterinary Institute: Oslo, Norway, 2008.

32. Toft, N.; Åkerstedt, J.; Tharaldsen, J.; Hopp, P. Evaluation of three serological tests for diagnosis of Maedi-Visna virus infection using latent class analysis. Vet. Microbiol. 2007, 120, 77-86. [CrossRef]

33. Singh, I.; McConnell, I.; Blacklaws, B. Immune Response to Individual Maedi-Visna Virus gag Antigens. J. Virol. 2006, 80, 912-919. [CrossRef]

34. Barquero, N.; Domenech, A.; Gomez-lucia, E. Caprine Arthritis-Encephalitis Virus. In Molecular Detection of Animal Viral Pathogens; Liu, D., Ed.; CRC Press: Boca Raton, FL, USA, 2016; pp. 157-162.

35. Houwers, D.J.; König, C.D.; Bakker, J.; de Boer, M.J.; Pekelder, J.J.; Sol, J.; Vellema, P.; de Vries, G. Maedi-visna control in sheep. III: Results and evaluation of a voluntary control program in The Netherlands over a period of four years. Vet. Q. 1987, 9 (Suppl. S1), 29-36. [CrossRef]

36. Tavella, A.; Bettini, A.; Ceol, M.; Zambotto, P.; Stifter, E.; Kusstatscher, N.; Lombardi, R.; Nardeli, S.; Beato, M.S.; Capello, K.; et al. Achievements of an eradication programme against caprine arthritis encephalitis virus in South Tyrol, Italy. Vet. Rec. 2018, $182,51$. [CrossRef] 
37. Cardinaux, L.; Zahno, M.L.; Deubelbeiss, M.; Zanoni, R.; Vogt, H.R.; Bertoni, G. Virological and phylogenetic characterization of attenuated small ruminant lentivirus isolates eluding efficient serological detection. Vet. Microbiol. 2013, 162, 572-581. [CrossRef] [PubMed]

38. Schlup, B. SU5-Peptid-ELISA als zusätzliches Bestätigungsverfahren für die SRLV-Diagnostik. Ph.D. Thesis, Institut für VeterinärVirologie der Universität Bern, Bern, Switzerland, 2009.

39. De Martin, E.; Golomingi, A.; Zahno, M.L.; Cachim, J.; Di Labio, E.; Perler, L.; Abril, C.; Zanoni, R.; Bertoni, G. Diagnostic response to a cross-border challenge for the Swiss caprine arthritis encephalitis virus eradication program. Schweiz. Arch. Tierheilkd. 2019, 161, 93-104. [CrossRef]

40. Mordasini, F.; Vogt, H.R.; Zahno, M.L.; Maeschli, A.; Nenci, C.; Zanoni, R.; Peterhans, E.; Bertoni, G. Analysis of the antibody response to an immunodominant epitope of the envelope glycoprotein of a lentivirus and its diagnostic potential. J. Clin. Microbiol. 2006, 44, 981-991. [CrossRef] [PubMed]

41. Rosati, S.; Kwang, J.; Tolari, F.; Keen, J. A comparison of whole virus and recombinant transmembrane ELISA and immunodiffusion for detection of ovine lentivirus antibodies in Italian sheep flocks. Vet. Res. Commun. 1994, 18, 73-80. [CrossRef] [PubMed]

42. Heckert, R.A.; McNab, W.B.; Richardson, S.M.; Briscoe, M.R. Evaluation of an enzyme-linked immunosorbent assay for the detection of antibodies to caprine arthritis-encephalitis virus in goat serum. Can. J. Vet. Res. 1992, 56, 237-241. [CrossRef] [PubMed]

43. Herrmann, L.M.; Cheevers, W.P.; Marshall, K.L.; McGuire, T.C.; Hutton, M.M.; Lewis, G.S.; Knowles, D.P. Detection of serum antibodies to ovine progressive pneumonia virus in sheep by using a caprine arthritis-encephalitis virus competitive-inhibition enzyme-linked immunosorbent assay. Clin. Diagn. Lab. Immunol. 2003, 10, 862-865. [CrossRef]

44. Herrmann, L.M.; Cheevers, W.P.; McGuire, T.C.; Adams, D.S.; Hutton, M.M.; Gavin, W.G.; Knowles, D.P. Competitive-inhibition enzyme-linked immunosorbent assay for detection of serum antibodies to caprine arthritis-encephalitis virus: Diagnostic tool for successful eradication. Clin. Diagn. Lab. Immunol. 2003, 10, 267-271. [CrossRef]

45. Houwers, D.J.; Schaake, J. An improved ELISA for the detection of antibodies to ovine and caprine lentiviruses, employing monoclonal antibodies in a one-step assay. J. Immunol. Methods 1987, 98, 151-154. [CrossRef]

46. Saman, E.; Van Eynde, G.; Lujan, L.; Extramiana, B.; Harkiss, G.; Tolari, F.; Gonzàlez, L.; Amorena, B.; Watt, N.; Badiola, J. A new sensitive serological assay for detection of lentivirus infections in small ruminants. Clin. Diagn. Lab. Immunol. 1999, 6, 734-740. [CrossRef]

47. Adjadj, N.R.; Vicca, J.; Michiels, R.; De Regge, N. (Non-)sense of milk testing in small ruminant lentivirus control programs in goats. Comparative analysis of antibody detection and molecular diagnosis in blood and milk. Viruses 2019, 12. [CrossRef] [PubMed]

48. Barquero, N.; Arjona, A.; Domenech, A.; Toural, C.; De Las Heras, A.; Fernández-Garayzabal, J.F.; Ruiz-Santa Quiteria, J.A.; Gomez-Lucia, E. Paper: Diagnostic performance of PCR and ELISA on blood and milk samples and serological survey for small ruminant lentiviruses in central Spain. Vet. Rec. 2011, 168, 20. [CrossRef] [PubMed]

49. Brinkhof, J.M.A.; Houwers, D.J.; Moll, L.; Dercksen, D.; van Maanen, C. Diagnostic performance of ELISA and PCR in identifying SRLV-infected sheep and goats using serum, plasma and milk samples and in early detection of infection in dairy flocks through bulk milk testing. Vet. Microbiol. 2010, 142, 193-198. [CrossRef] [PubMed]

50. Mazzei, M.; Carrozza, M.L.; Bandecchi, P.; Mazzanti, G.; Mannelli, A.; Tolari, F. Evaluation of an ELISA to detect antibodies to maedi-visna virus in individual and pooled samples of milk from sheep. Vet. Rec. 2005, 157, 552-555. [CrossRef]

51. Potărniche, A.V.; Czopowicz, M.; Szaluś-Jordanow, O.; Moroz, A.; Mickiewicz, M.; Witkowski, L.; Markowska-Daniel, I.; Bagnicka, E.; Cerbu, C.; Olah, D.; et al. Diagnostic accuracy of three commercial immunoenzymatic assays for small ruminant lentivirus infection in goats performed on individual milk samples. Prev. Vet. Med. 2021, 191. [CrossRef]

52. Barquero, N.; Gomez-Lucia, E.; Arjona, A.; Toural, C.; Las Heras, A.; Fernández-Garayzabal, J.F.; Domenech, A. Evolution of specific antibodies and proviral DNA in milk of small ruminants infected by small ruminant lentivirus. Viruses 2013, 5, 2614-2623. [CrossRef] [PubMed]

53. Plaza, M.; Sánchez, A.; Corrales, J.C.; De la Fe, C.; Contreras, A. Caprine arthritis encephalitis virus diagnosed by ELISA in lactating goats using milk samples. Small Rumin. Res. 2009, 81, 189-192. [CrossRef]

54. Lacerenza, D.; Giammarioli, M.; Grego, E.; Marini, C.; Profiti, M.; Rutili, D.; Rosati, S. Antibody response in sheep experimentally infected with different small ruminant lentivirus genotypes. Vet. Immunol. Immunopathol. 2006, 112, 264-271. [CrossRef]

55. Brinkhof, J.; Van Maanen, C. Evaluation of five enzyme-linked immunosorbent assays and an agar gel immunodiffusion test for detection of antibodies to small ruminant lentiviruses. Clin. Vaccine Immunol. 2007, 14, 1210-1214. [CrossRef]

56. Sardi, S.I.; Torres, J.A.; Brandão, C.F.L.; Tigre, D.M.; Campos, G.S. Early Detection of goats infected with Lentivirus Small Ruminant virus by ELISA assay. Rev. Ciências Méd. Biol. 2012, 11, 35. [CrossRef]

57. Sanjosé, L.; Pinczowski, P.; Crespo, H.; Pérez, M.; Glaria, I.; Gimeno, M.; de Andrés, D.; Amorena, B.; Luján, L.; Reina, R. Diagnosing infection with small ruminant lentiviruses of genotypes A and B by combining synthetic peptides in ELISA. Vet. J. 2015, 204, 88-93. [CrossRef] [PubMed]

58. de Andrés, X.; Ramírez, H.; Bertolotti, L.; San Román, B.; Glaria, I.; Crespo, H.; Jáuregui, P.; Minguijón, E.; Juste, R.; Leginagoikoa, I.; et al. An insight into a combination of ELISA strategies to diagnose small ruminant lentivirus infections. Vet. Immunol. Immunopathol. 2013, 152, 277-288. [CrossRef] 
59. Nogarol, C.; Bertolotti, L.; Klevar, S.; Profiti, M.; Gjerset, B.; Rosati, S. Serological characterization of small ruminant lentiviruses: A complete tool for serotyping lentivirus infection in goat. Small Rumin. Res. 2019, 176, 42-46. [CrossRef]

60. Reina, R.; Grego, E.; Profiti, M.; Glaria, I.; Robino, P.; Quasso, A.; Amorena, B.; Rosati, S. Development of specific diagnostic test for small ruminant lentivirus genotype E. Vet. Microbiol. 2009, 138, 251-257. [CrossRef] [PubMed]

61. Leginagoikoa, I.; Minguijón, E.; Berriatua, E.; Juste, R.A. Improvements in the detection of small ruminant lentivirus infection in the blood of sheep by PCR. J. Virol. Methods 2009, 156, 145-149. [CrossRef] [PubMed]

62. Ramírez, H.; Echeverría, I.; Benito, A.A.; Glaria, I.; Benavides, J.; Pérez, V.; de Andrés, D.; Reina, R. Accurate diagnosis of small ruminant lentivirus infection is needed for selection of resistant sheep through tmem154 e35k genotyping. Pathogens 2021, 10, 1-16. [CrossRef] [PubMed]

63. Echeverría, I.; De Miguel, R.; De Pablo-Maiso, L.; Glaria, I.; Benito, A.A.; De Blas, I.; De Andrés, D.; Luján, L.; Reina, R. MultiPlatform Detection of Small Ruminant Lentivirus Antibodies and Provirus as Biomarkers of Production Losses. Front. Vet. Sci. 2020, 7, 182. [CrossRef]

64. Nowicka, D.; Czopowicz, M.; Mickiewicz, M.; Szalus-Jordanow, O.; Witkowski, L.; Bagnicka, E.; Kaba, J. Diagnostic performance of ID Screen ${ }^{\circledR}$ MVV-CAEV Indirect Screening ELISA in identifying small ruminant lentiviruses-infected goats. Pol. J. Vet. Sci. 2014, 17, 501-506. [CrossRef]

65. Varea, R.; Monleón, E.; Pacheco, C.; Luján, L.; Bolea, R.; Vargas, M.A.; Van Eynde, G.; Saman, E.; Dickson, L.; Harkiss, G.; et al. Early detection of maedi-visna (ovine progressive pneumonia) virus seroconversion in field sheep samples. J. Vet. Diagnostic Investig. 2001, 13, 301-307. [CrossRef]

66. Zanoni, R.G.; Vogt, H.-R.; Pohl, B.; Böttcher, J.; Bommeli, W.; Peterhans, E. An ELISA Based on Whole Virus for the Detection of Antibodies to Small-ruminant Lentiviruses. J. Vet. Med. Ser. B 1994, 41, 662-669. [CrossRef]

67. Reina, R.; Berriatua, E.; Luján, L.; Juste, R.; Sánchez, A.; de Andrés, D.; Amorena, B. Prevention strategies against small ruminant lentiviruses: An update. Vet. J. 2009, 182,31-37. [CrossRef]

68. Angelopoulou, K.; Brellou, G.D.; Vlemmas, I. Detection of Maedi-Visna Virus in the Kidneys of Naturally Infected Sheep. J. Comp. Pathol. 2006, 134, 329-335. [CrossRef]

69. Brellou, G.D.; Angelopoulou, K.; Poutahidis, T.; Vlemmas, I. Detection of Maedi-Visna Virus in the Liver and Heart of Naturally Infected Sheep. J. Comp. Pathol. 2007, 136, 27-35. [CrossRef] [PubMed]

70. Extramiana, A.B.; González, L.; Cortabarría, N.; García, M.; Juste, R.A. Evaluation of a PCR technique for the detection of Maedi-Visna proviral DNA in blood, milk and tissue samples of naturally infected sheep. Small Rumin. Res. 2002, 44, 109-118. [CrossRef]

71. Leroux, C.; Lerondelle, C.; Chastang, J.; Mornex, J.F. RT-PCR detection of lentiviruses in milk or mammary secretions of sheep or goats from infected flocks. Vet. Res. 1997, 28, 115-121. [CrossRef] [PubMed]

72. Pinczowski, P.; Sanjosé, L.; Gimeno, M.; Crespo, H.; Glaria, I.; Amorena, B.; de Andrés, D.; Pérez, M.; Reina, R.; Luján, L. Small Ruminant Lentiviruses in Sheep: Pathology and Tropism of 2 Strains Using the Bone Marrow Route. Vet. Pathol. 2017, 54, 413-424. [CrossRef]

73. Singh, R.; Kumar, P.; Singh, R.; Dhama, K.; Kumari, S.; Yadav, J.P.; Kashyap, G.; Singh, K.P.; Singh, V.; Sahoo, M. Pathology and polymerase chain reaction detection of ovine progressive pneumonia (maedi) cases in slaughtered sheep in India. Vet. World 2017, 10, 1401-1406. [CrossRef] [PubMed]

74. Peterson, K.; Brinkhof, J.; Houwers, D.J.; Colenbrander, B.; Gadella, B.M. Presence of pro-lentiviral DNA in male sexual organs and ejaculates of small ruminants. Theriogenology 2008, 69, 433-442. [CrossRef]

75. Villoria, M.; Leginagoikoa, I.; Luján, L.; Pérez, M.; Salazar, E.; Berriatua, E.; Juste, R.A.; Minguijón, E. Detection of Small Ruminant Lentivirus in environmental samples of air and water. Small Rumin. Res. 2013, 110, 155-160. [CrossRef]

76. Zanoni, R.; Pauli, U.; Peterhans, E. Detection of caprine arthritis-encephalitis- and maedi-visna viruses using the polymerase chain reaction. Experientia 1990, 46, 316-319. [CrossRef] [PubMed]

77. Gjerset, B.; Rimstad, E.; Teige, J.; Soetaert, K.; Jonassen, C.M. Impact of natural sheep-goat transmission on detection and control of small ruminant lentivirus group C infections. Vet. Microbiol. 2009, 135, 231-238. [CrossRef] [PubMed]

78. Panneum, S.; Rukkwamsuk, T. Diagnosis of Caprine Arthritis Encephalitis Virus infection in dairy goats by ELISA, PCR and Viral Culture. Pol. J. Vet. Sci. 2017, 20, 347-353. [CrossRef]

79. Olech, M.; Rachid, A.; Croisé, B.; Kuźmak, J.; Valas, S. Genetic and antigenic characterization of small ruminant lentiviruses circulating in Poland. Virus Res. 2012, 163, 528-536. [CrossRef]

80. Eltahir, Y.M.; Dovas, C.I.; Papanastassopoulou, M.; Koumbati, M.; Giadinis, N.; Verghese-Nikolakaki, S.; Koptopoulos, G. Development of a semi-nested PCR using degenerate primers for the generic detection of small ruminant lentivirus proviral DNA. J. Virol. Methods 2006, 135, 240-246. [CrossRef]

81. Barquero, N.; Domenech, A.; Arjona, A.; Fernández-Garayzabal, J.F.; Ruiz-Santa-Quiteria, J.A.; Gomez-Lucia, E. Comparison of two PCR and one ELISA techniques for the detection of small ruminant lentiviruses (SRLVs) in milk of sheep and goats. Res. Vet. Sci. 2013, 94, 817-819. [CrossRef] [PubMed]

82. Brinkhof, J.M.A.; van Maanen, C.; Wigger, R.; Peterson, K.; Houwers, D.J. Specific detection of small ruminant lentiviral nucleic acid sequences located in the proviral long terminal repeat and leader-gag regions using real-time polymerase chain reaction. $J$. Virol. Methods 2008, 147, 338-344. [CrossRef] 
83. Kuhar, U.; Barlič-Maganja, D.; Grom, J. Development and validation of TaqMan probe based real time PCR assays for the specific detection of genotype A and B small ruminant lentivirus strains. BMC Vet. Res. 2013, 9, 172. [CrossRef]

84. Chassalevris, T.; Chaintoutis, S.C.; Apostolidi, E.D.; Giadinis, N.D.; Vlemmas, I.; Brellou, G.D.; Dovas, C.I. A highly sensitive semi-nested real-time PCR utilizing oligospermine-conjugated degenerate primers for the detection of diverse strains of small ruminant lentiviruses. Mol. Cell. Probes 2020, 51, 101528. [CrossRef]

85. Brajon, G. Development and Field Testing of a Real-Time PCR Assay for Caprine Arthritis-Encephalitis-Virus (CAEV). Open Virol. J. 2012, 6, 82-90. [CrossRef]

86. De Regge, N.; Cay, B. Development, validation and evaluation of added diagnostic value of a $q(R T)-P C R$ for the detection of genotype A strains of small ruminant lentiviruses. J. Virol. Methods 2013, 194, 250-257. [CrossRef]

87. Psifidi, A.; Dovas, C.I.; Banos, G. A comparison of six methods for genomic DNA extraction suitable for PCR-based genotyping applications using ovine milk samples. Mol. Cell. Probes 2010, 24, 93-98. [CrossRef] [PubMed]

88. Zhang, Z.; Watt, N.J.; Hopkins, J.; Harkiss, G.; Woodall, C.J. Quantitative analysis of maedi-visna virus DNA load in peripheral blood monocytes and alveolar macrophages. J. Virol. Methods 2000, 86, 13-20. [CrossRef]

89. Highland, M.A. Small Ruminant Lentiviruses: Strain Variation, Viral Tropism, and Host Genetics Influence Pathogenesis. Vet. Pathol. 2017, 54, 353-354. [CrossRef]

90. Zanoni, R.G.; Nauta, I.M.; Kuhnert, P.; Pauli, U.; Pohl, B.; Peterhans, E. Genomic heterogeneity of small ruminant lentiviruses detected by PCR. Vet. Microbiol. 1992, 33, 341-351. [CrossRef]

91. Dolfini, T.; Conrad, L.F.; Flores, I.V.C.; Ravazzolo, A.P. Comparison of primer pairs: Greater degeneracy improves small ruminant lentivirus (SRLVs) detection by seminested PCR. Small Rumin. Res. 2015, 123, 189-192. [CrossRef]

92. Germain, K.; Valas, S. Distribution and heterogeneity of small ruminant lentivirus envelope subtypes in naturally infected French sheep. Virus Res. 2006, 120, 156-162. [CrossRef]

93. Germain, K.; Croise, B.; Valas, S. Field evaluation of a gag/env heteroduplex mobility assay for genetic subtyping of smallruminant lentiviruses. J. Gen. Virol. 2008, 89, 2020-2028. [CrossRef]

94. Pisoni, G.; Bertoni, G.; Puricelli, M.; Maccalli, M.; Moroni, P. Demonstration of Coinfection with and Recombination by Caprine Arthritis-Encephalitis Virus and Maedi-Visna Virus in Naturally Infected Goats. J. Virol. 2007, 81, 4948-4955. [CrossRef] [PubMed]

95. Pisoni, G.; Moroni, P.; Turin, L.; Bertoni, G. Compartmentalization of small ruminant lentivirus between blood and colostrum in infected goats. Virology 2007, 369, 119-130. [CrossRef] [PubMed]

96. Huang, J.; Sun, Y.; Liu, Y.; Xiao, H.; Zhuang, S. Development of a loop-mediated isothermal amplification method for rapid detection of caprine arthritis-encephalitis virus proviral DNA. Arch. Virol. 2012, 157, 1463-1469. [CrossRef] [PubMed]

97. Balbin, M.M.; Belotindos, L.P.; Abes, N.S.; Mingala, C.N. Caprine arthritis encephalitis virus detection in blood by loop-mediated isothermal amplification (LAMP) assay targeting the proviral gag region. Diagn. Microbiol. Infect. Dis. 2014, 79, 37-42. [CrossRef] [PubMed]

98. Tu, P.A.; Shiu, J.S.; Lee, S.H.; Pang, V.F.; Wang, D.C.; Wang, P.H. Development of a recombinase polymerase amplification lateral flow dipstick (RPA-LFD) for the field diagnosis of caprine arthritis-encephalitis virus (CAEV) infection. J. Virol. Methods 2017, 243, 98-104. [CrossRef] [PubMed]

99. Barros, S.C.; Andrésdóttir, V.; Fevereiro, M. Cellular specificity and replication rate of Maedi Visna virus in vitro can be controlled by LTR sequences. Arch. Virol. 2005, 150, 201-213. [CrossRef]

100. Colitti, B.; Coradduzza, E.; Puggioni, G.; Capucchio, M.T.; Reina, R.; Bertolotti, L.; Rosati, S. A new approach for small ruminant lentivirus full genome characterization revealed the circulation of divergent strains. PLoS ONE 2019, 14, e0212585. [CrossRef]

101. Karanikolaou, K.; Angelopoulou, K.; Papanastasopoulou, M.; Koumpati-Artopiou, M.; Papadopoulos, O.; Koptopoulos, G. Detection of small ruminant lentiviruses by PCR and serology tests in field samples of animals from Greece. Small Rumin. Res. 2005, 58, 181-187. [CrossRef]

102. Brinkhof, J.; Maanen, K. Detection and Control of Lentiviral Infections in Sheep and Goats; Jan Brinkhof: Utrecht, The Netherlands, 2010; Volume 2010, ISBN 978-90-393-51796.

103. Herrmann-Hoesing, L.M.; Palmer, G.H.; Knowles, D.P. Evidence of proviral clearance following postpartum transmission of an ovine lentivirus. Virology 2007, 362, 226-234. [CrossRef]

104. Pai, N.P.; Karellis, A.; Kim, J.; Peter, T. Modern diagnostic technologies for HIV. Lancet HIV 2020, 7, e574-e581. [CrossRef] 